\title{
The Sculpted Word
}




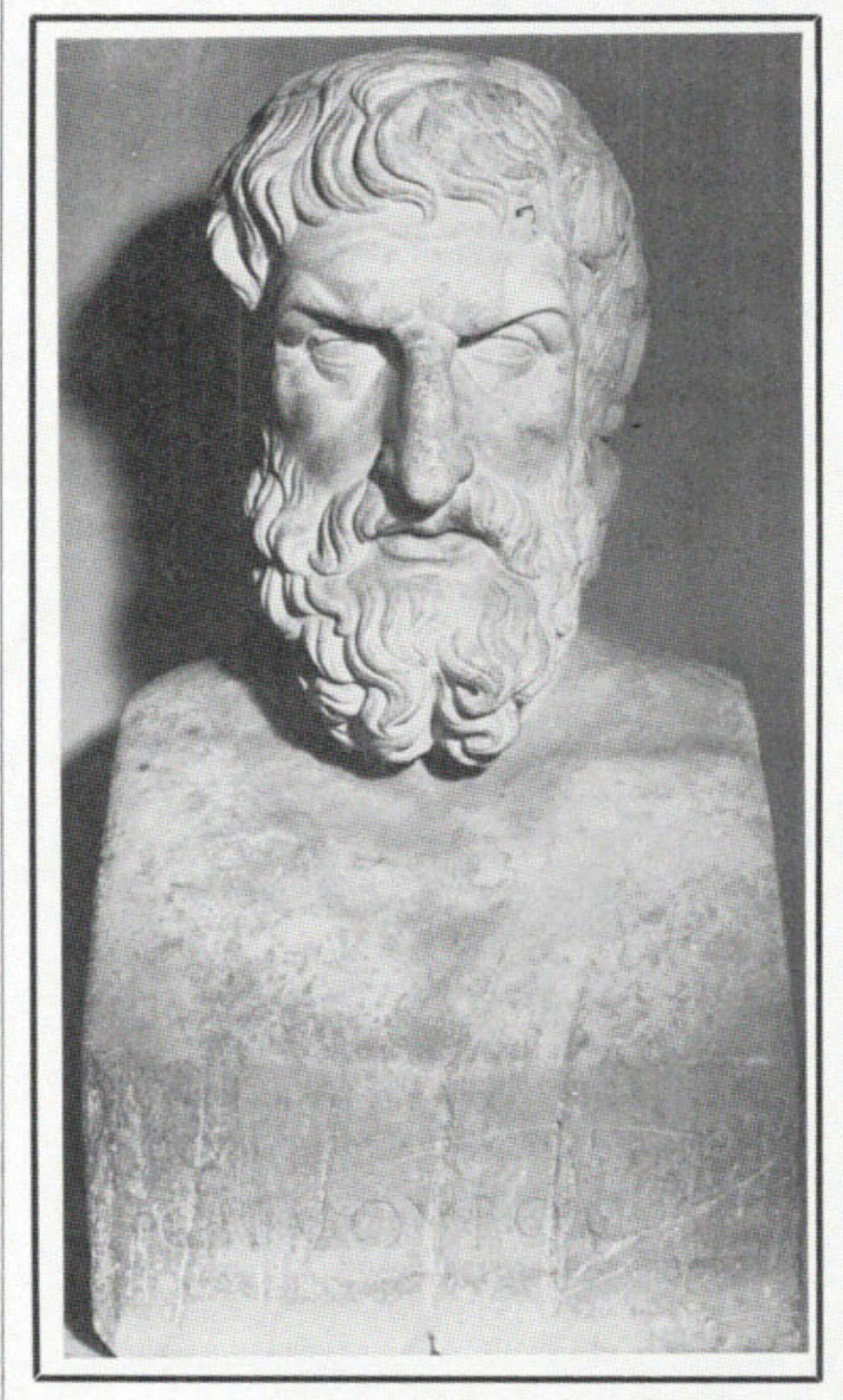

Bust of Epicurus. 


\section{The Sculpted Word}

Epicureanism and

Philosophical Recruitment in Ancient Greece

BERNARD FRISCHER

University of California Press

Berkeley Los Angeles London 
University of California Press

Berkeley and Los Angeles, California

University of California Press, Ltd.

London, England

(C) 1982 by

The Regents of the University of California

Printed in the United States of America

$\begin{array}{lllllllll}1 & 2 & 3 & 4 & 5 & 6 & 7 & 8 & 9\end{array}$

Library of Congress Cataloging in Publication Data

Frischer, Bernard.

The sculpted word.

Bibliography: p.

Includes indexes.

I. Epicurus. 2. Philosophy, Ancient. I. Title.

$\begin{array}{lrl}\text { B573.F74 } & \text { I 87 } & \text { 8 I-I 3 I 43 } \\ \text { ISBN 0-520-04 I9O-9 } & \text { AACR2 }\end{array}$ 
ACADEMIAE AMERICANAE

ROMAE SITAE 
